\title{
Entrepreneurship, Local Growth and Global Markets
}

\author{
Giuseppe Cappiello*
}

\begin{abstract}
The creation or start-up of new companies has been the subject of extensive discussion in recent years, both at a scientific and a political level. The reason for this lies primarily in the hope that new businesses will contribute to local development and employment.

The birth of new businesses concerns three dimensions: the subjective one, the context in which the company was founded and the strategic choices made.

These choices are particularly useful in understanding that an organic, allencompassing design is required, especially if a global ecosystem is involved. At the same time, it seems necessary for the State to play an enabling role.
\end{abstract}

Keywords: Start-Up; Global Markets; Entrepreneurship; Local Growth; Innovation; Start-Up Ecosystem; New Entreprise Creation

\section{Innovation and Entrepreneurship}

To be innovative and meet the challenges posed by competition and market globalization (Brondoni, 2008), every firm or geographical area must possess a strong entrepreneurial culture ${ }^{1}$, because, as widely argued from Schumpeter onwards, innovation and entrepreneurship are closely related ${ }^{2}$.

Entrepreneurs are innovative because they introduce new models, seek new resources, take the risk of exploring uncharted territory and create value by transforming ideas into real goods and services and overcoming the "knowledge filter" (Audretsch, 2009) or anything else that prevents or slows the economic exploitation of new solutions.

$\square$ Audretsch uses the expression "knowledge filter" to explain that investment in research and human capital are necessary, but not enough to create development and employment. The so-called knowledge filter, created either by public bureaucracy or the routines of big business, stands between the generation of new ideas and their transformation into new products or services ready for the market. According to the author, Europe

\footnotetext{
* Assistant Professor of Management, Alma Mater Studiorum - University of Bologna (giuseppe.cappiello@unibo.it)
} 
"has no shortage of people trained in science or engineering, and certainly no shortage of educated, creative and serious minds, but what happens if companies do not take advantage of all this preparation, this culture, this research, this creativity, and in short, the new breakthroughs made by individuals? Why should a large successful company ignore its most valuable asset, namely the ideas of intelligent, creative and talented employees? The truth is they do so on purpose."

Innovating does not necessarily mean inventing something that was not there before, like a technological solution, for example. It also means rethinking competitive positioning and reorganizing business assets, processes and market approaches in a more efficient, more competitive manner.

So it is not difficult to accept the argument that the entrepreneur is the main innovator, as they are the economic actors who qualify as the ones who "discover" (Kirzner, 1997) and "exploit" (Shane and Venkataraman 2000) opportunities for improvement that others often do not even see.

This explains why so much public funding and so many local, national and supranational programs are channelled into supporting entrepreneurship, because the entrepreneur is seen as a leading resource for both development and employment.

Starting, then, from the conviction that entrepreneurship is essential to any given region because it stimulates innovation and competitiveness, this paper seeks to contextualize the start-up of a new enterprise in an ecosystem consisting of a plurality of actors who constantly interact to create value by identifying new opportunities.

Current scientific literature focuses particularly on the figure of the entrepreneur in any new business, whereas studies on innovation often neglect the entrepreneur and concentrate primarily on institutions and structures (Acs et al, 2014). The entrepreneurial phenomenon, conversely, is systemic and involves a wide range of players. It is also never isolated from the environment it engages with, and, more importantly, it connects the local to the global, and the present to the future.

In this sense, there are at least three dimensions of the entrepreneurial phenomenon (Figure 1) that need to be analysed: the subjective nature of entrepreneurship, the context in which entrepreneurs and their businesses are born and grow, and the strategic importance of established businesses with the need to keep an entrepreneurial spirit alive.

Figure 1: New Firm Creation

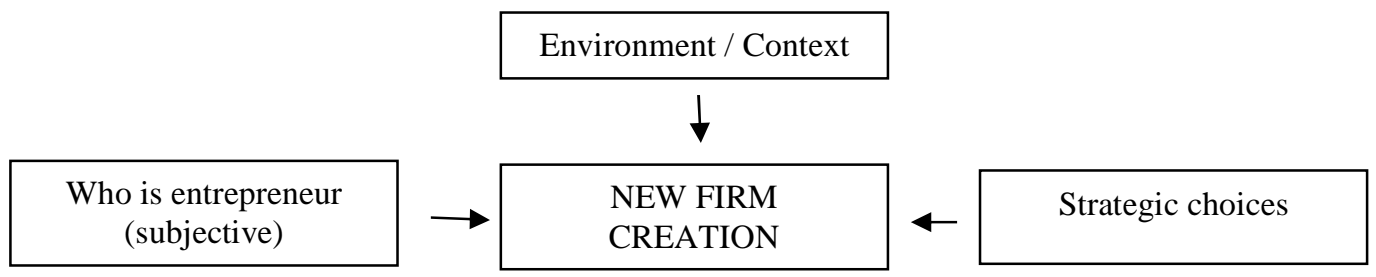




\section{The Creation of New Enterprises}

The interest in the creation processes of new businesses has grown since the end of the 1970s as a result of the technological, economic and social changes that have challenged the assumption that large enterprises are the only real drivers of economic development.

As shown in an interesting reconstruction by Audretsch (2009), after World War II large companies were responsible for an extraordinary leap in economic growth. The lives of many families, the layout of urban areas and, more generally, the shape of society itself was moulded by major enterprises. Young people automatically saw themselves working in one of these companies in the future and fathers took this state of affairs for granted. Thanks to the efficiency of the scientific production system, for example, in twenty years Ford had succeeded in lowering the price of its standard Ford T model to less than $\$ 300$ and workers, who earned $\$ 5$ a day, could actually buy the car they had helped build.

It then became clear that the rise of these enterprises, based on the use of capital, generated a more affluent social class and large-scale consumption, even if in the longterm this would lead to 'jobless growth'. In order to remain competitive in markets that were widening on both a multinational and a global scale, large companies had to minimize staff costs by moving to locations where production was cheaper. At the same time, these enterprises, despite having higher research budgets, found it difficult to take advantage of innovations and new market opportunities as internal routines had become over complex and inflexible. This led to a surge in new and innovative ventures that were seen by scholars and policy makers as an opportunity to introduce radical changes. In the 1990s America's quick reaction to a crisis that threatened its world leadership was also thanks to the development of an 'entrepreneurial society'.

The increasing attention paid by scholars to the phenomenon of new businesses was mirrored by an increase in the number of new entrepreneurial training programs. In 1970 in the United States only 16 business schools offered a course on entrepreneurship. In 1995, the courses had grown to about 440 and more than 50 universities provided at least 4 courses on this topic.

Entrepreneurial dynamics are especially relevant to the capacity of new businesses to create jobs and in recent decades in the United States, firms that are less than a year old have created an average of 1.5 million jobs (Kaufman Foundation, 2014). More generally, small businesses contribute significantly to the net balance of jobs created and this has given rise to an inverse relationship between the size of businesses and new jobs ${ }^{3}$. New businesses tend to hire younger people by virtue of their higher risk tolerance and the availability of specific skills, so regions with a higher percentage of forward-thinking young people can also count on a larger number of innovative startups (Ouimet \& Zarutskie, 2014).

For various reasons that can be traced back in history to poverty or backwardness, or more recently to substantial state and bank intervention, Italy has always been characterized by widespread entrepreneurship, even if the vast number of companies have traditionally remained small affairs apart from a few large family-based industries. Amatori (1980) classified Italian entrepreneurs into three categories: 
"private", "supported" and "public". The first group are traditional entrepreneurs, the second have entered business after being funded by third parties (often public policies and financial incentives), whereas the third category are entrepreneurs, who have been set up directly by the state itself.

A more recent study on the roots of Italian capitalism (Toninelli \& Vasta, 2010), focused on the period between the unification of Italy and the so-called 'economic miracle' after World War II, provides an identikit of the figures who created the entrepreneurial fabric of Italy at this time. These are people with an above average education, business experience based mainly on family relations and real international market opportunities. Despite these advantages, the level of innovation was generally poor, partly due to non-technical-scientific studies and a lack of versatility caused by many factors, like national welfare policies that weakened entrepreneur's appetite for risk and distanced their choices from the market.

At the same time, we cannot forget the countless success stories that have made Italy famous and the brilliance of lots entrepreneurs who have become sector leaders and exported their products all over the world. The same is true of the business models of a number of Italian industrial districts (Becattini, 2004) that have been widely observed internationally. These are important here, on account of the influence they have on the subjective element of entrepreneurship through relationship networks and shared visions and values.

The latest Global Entrepreneurship Monitor report (GEM 2014), a major research program involving approximately 200,000 people in 73 countries from all around the world, puts Italy in last place in terms of Innovation Drive, with a rate of total new entrepreneurship (TEA, Total Early-Stage Entrepreneurship Activity) of 4.4\% among the adult population compared to $13.8 \%$ in the United States. This is undoubtedly the result of problems related to bureaucracy, the tax system and the slow pace of justice that, for many years, have prevented the undoubted potential that exists in Italy from being fully exploited.

$\square$ GEM refers to "Innovation-Driven" countries where companies are founded on knowledge and the service sector is highly developed. These are distinguished from "factor driven" countries whose production is based on agriculture and natural resources that do not require a qualified workforce and "efficiency driven" countries with capital intensive industrialization that exploits economies of scale.

From a personal profile point of view, current entrepreneurs are very different from their predecessors. $24 \%$ of the 90,200 new companies set up in Italy in the first half of 2014 were founded by the under 30 age group, while a further $17 \%$ were founded by the 30 to 35 age group. These young people (60\% males and $40 \%$ females, $48 \%$ graduates and $22 \%$ with a secondary school education) founded small enterprises that have few resources but boast a strong propensity for applying new technology and social networks to trade and business services because their founders are digital natives ${ }^{4}$. 
The arguments in favour of new enterprises and the easy enthusiasm aroused by the various events organized to promote entrepreneurship have led the world's political classes to see entrepreneurs as a solution for recession, but this attitude has been criticised. A Forbes magazine article provocatively entitled "Seven Reasons Why Startups Will Not Save the Economy", for example, warns against this "Start-upmania" and invites us to shun short-term recipes in favour of long-term perspectives that support not only the foundation of enterprises, but also their growth and the way they target their investments.

\section{The Subjective Dimension}

In early studies on entrepreneurship a considerable effort was made to reach a precise definition of the figure of the entrepreneur and to identify what differentiates an entrepreneur from a non-entrepreneur. The result was the construction of a kind of genetic predisposition and the idea that certain people are 'born entrepreneurs'. From the meta-analysis carried out by Rauch and Frese (2007) on existing studies, a positive, albeit moderate, relationship emerges between certain personality traits of the "business owner" and the creation and success of their enterprise. This line of study, which is grouped in the so-called "trait theory", seeks to prove that entrepreneurs have specific characteristics and three in particular: a strong desire for self-realization (need for achievement), the need to feel in control (locus of control) and a propensity for risk-taking.

According to McClelland (1965), the desire for self-realization stretches certain people as they set themselves ambitious targets and are then strongly motivated to reach them. These characters are generally not afraid of overcoming obstacles as these targets often exist simply to be reached and not for any tangible benefit.

The locus of control construct refers to the degree to which a person believes that they are in control of the outcome of events in their lives, rather than external forces beyond their control (Rotter, 1966). People with an external locus of control believe that they are unlikely to control events in their lives and that whatever happens can be attributed to external circumstances, that are independent and uncontrollable. Conversely, people with an internal locus of control feel that they are masters of their own fate, because they determine it with their own skills and commitment. Miller and Toulouse (1986) suggest that entrepreneurs with an internal locus of control achieve higher levels of performance, especially when operating in dynamic environments.

Lastly, propensity for risk-taking defines a person's tendency to take or avoid a risky situation in order to gain an advantage.

A number of other traits can be added to these three main qualities, such as an ability to handle uncertainty, a capacity to adapt, measured by the speed of decision-making, and a willingness to learn from mistakes and alter beliefs and assumptions.

Despite their popularity, other studies of entrepreneurship have ignored these personal qualities and sought to explain entrepreneurial success by focusing on the 'situation' in which the aspiring entrepreneur has to operate. 
Both these approaches, however, have been widely criticised as this issue is far too complex for these factors to be separated. Attempting to analyse how they interact, on the other hand, is an approach that is much more likely to give us a real insight into the ramifications of a business start-up. These interactive theories state that both 'genetic and environmental factors contribute to the formation of an entrepreneurial profile.' They take into account both the endogenous variables of the aspiring entrepreneur (gender and age) and the exogenous variables (previous experience, social, cultural and economic trends, parental models and historical and cultural traditions). In the first variable, gender has a strong impact on the decision to become an entrepreneur, as numerous studies show that males have a greater propensity to become entrepreneurs (even if this trend is decreasing). The second variable, on the other hand, demonstrate the important role that business relationship facilitators play in terms of the entrepreneur and the surrounding actors and business environment.

Recent literature tends to use a multidimensional approach that includes both antecedent factors such as personality traits, family and education levels, as well as the influence of external organizations, geographical location and available capital. In any case, the tendency is usually to focus on the individual character of a start-up and to leave existing businesses in the background, while focussing alternately on entrepreneurial orientation or orientation to the market. In a later section we will attempt to reconcile these two orientations.

Gartner (1988), however, believes that the "Who is the entrepreneur?" is the wrong question and disputes any approach that identifies entrepreneurship with the traits and behaviour of the entrepreneur, as entrepreneurship is only the act of creating an organization that was not there before.

\section{The Context Factor}

Another perspective of entrepreneurship analysis refers to the environment in which innovative ideas appear and develop into an enterprise (Autio et al 2014).

Existing legislation, for example, has a powerful effect on the rate of start-ups. In some countries, for example, bankruptcy legislation is less detrimental to those who have a past history of business failure, as they are cultures that do not regard failure as an unrecoverable defeat. Similarly, the costs and time for starting businesses vary from state to state, and this certainly affects decisions of where to locate a new business.

Companies are not solitary ventures either, as those who decide to embark on an entrepreneurial path need support structures especially at start-up and consolidation.

These needs can usually be split into two types: capital and know-how. As far as capital is concerned, Italy is known to be a country with an undeveloped market for venture capital, but interestingly, the number of institutions offering this kind of service is currently growing.

Know-how, on the other hand, is a very different issue, as the crisis that the country's largest manufacturing enterprises are currently undergoing has highlighted the strategic importance of this resource. In addition to traditional training providers and other operators who are attempting to promote a culture of entrepreneurship, collaboration 
and exchange of knowledge between different organizations oriented to innovation is mainly driven by geographical proximity. Therefore, since the 1980s, attempts have been made to reproduce the strategic advantages of proximity. Science parks (PST) are an example of this. A PST is a physical site designed and operated to facilitate the transfer of technology between companies, universities and research centres. Depending on the space and equipment available, these parks often hosts new businesses or spin-offs from existing ones as well as offering value-added services such as research and development, training, technology brokerage and marketing.

In Italy these science parks have been operating since the 1990s, thanks in particular to income from the Ministry of University and Scientific Research and contributions from the European Union. They are usually set up as consortia or joint-stock companies, but they exist in other legal formats too. At the moment the Italian Association of Science Parks and Technology, the organization created to support and represent these initiatives, has 27 members operating throughout Italy, but mainly in the North.

Business incubators, on the other hand, are one of the most common tools used to accompany attempts to create new businesses. From a chronological perspective, we have identified four key stages in the evolution of these structures in Europe. The first incubators, that were a kind of embryo of the current facilities, can be found at the end of the 1970s and were created from the ongoing transformation of traditional industry and the growing importance of information and communication technology. In the 1980s the number of projects and public funding grew significantly as incubators were seen as an economic policy instrument and a stimulus for entrepreneurial initiative and job creation. In the 1990s there was a degree of specialisation in terms of both sector and technological domains due to the spread of information technology. Since the year 2000 , large private companies have begun investing equity capital in the establishment of incubators and accelerators.

A study sponsored by the Bank of Italy, indicates that in line with European data, about two thirds of Italian incubators are public ${ }^{5}$.

The relationship between the entrepreneur and the local area is, therefore, not a onesided affair, as new enterprises contribute to the development of their location in terms of employment growth, increased affluence and new preferential relations with other territories. For example, a company that opens a subsidiary in a different area creates new corridors of understanding between the two territories. At the same time, the local area helps sustain new enterprises by providing to its own resources.

The concept of social capital (Coleman, 1988) is perhaps the best definition of this stock of relationships that may be strong or weak (Granovetter, 1973) and which influences the development of entrepreneurship and innovation in three different ways (Bondoni, 2014; Lambin 2014). These include providing information, creating business opportunities by enhancing mutual confidence and reducing transaction costs, and sharing values and standards (Presutti, Boari, 2007). The importance of this kind of relational capital is demonstrated by the emergence of entire start-up cities, where a series of entrepreneurs have chosen the same location because it is easier to meet investors and fellow entrepreneurs, share knowledge and develop corporate alliances 
(Brondoni, 2011). Silicon Valley is perhaps the best example of entrepreneurs and innovators coming together, in this case, in the field of digital and ICT technology.

\section{Strategic Entrepreneurship}

The third perspective to analyse regards entrepreneurship in organisations that already exist because entrepreneurial orientation characterizes new venture as far as wealthy a consolidated firms (Lumpkin and Dess, 1996). The television industry, for example, shows how new successful businesses can be created from existing successful enterprises, such as, in this case, radio (Arora A., Gambardella A. and S. Klepper, 2005). In fact, new enterprises are often developed from existing ones or by diversifying successful solutions into contiguous sectors. A classic example of this are the spin-offs often launched by a group of capable employees.

Similarly, an important driver for the creation of new enterprises or the revitalization of existing ones is the public research system. For example, researchers operating downstream from a search path in which marketable innovations have emerged, may decide to create an enterprise affiliated to the mother institution or embark on an entrepreneurial experience in partnership with others.

This leap into entrepreneurship may be driven by various requirements, such as the need for greater flexibility and autonomy than that offered by a university, a desire for greater social recognition, the need to monitor results more effectively, formally involve graduate students or recent graduates, find greater economic resources to ensure the project continues to grow or to stabilize relations with a company that has complementary means (laboratories, patents, expertise, etc.).

The birth rate of spin-offs from research varies greatly between universities and countries on account of both national and individual university legislation, and the culture that characterizes the specific organization or territory in which the enterprise is located. In Italy 1,144 spin-off companies were recorded as of December 31, 2014 (XII Netval Report, 2015).

These two trajectories of new companies that emerge from existing ones or start-ups that are rooted in public research, indicate that the boundaries between marketing strategies (a market-driven approach) and entrepreneurial orientation (a market-driving approach, Jaworsky, Kohli and Sahay 2000) are often blurred. In situations where an established market already exists or needs to be redefined, (think, for example, of the tablet as a breaking innovation in the electronics market), a new 'end user' or new uses for existing products has to be established. This means that the company must create discontinuities along its value chain or change its business model. In these cases, a typical entrepreneur will want to introduce new services or new distribution channels and sometimes the most effective way to do this may be to found new businesses or acquire start-ups instead of investing heavily in research and development (exogenous growth). 


\section{Conclusions}

In this work new venture creation has been analysed from three different perspectives: the character of the entrepreneur, the context in which the new business is created and strategic orientation in existing companies. The results have highlighted the fact that new business paths are necessarily activated within a network of relationships between various parties, public, private or hybrid that make up the socalled ecosystem of start-ups.

In a recent article addressed to the scientific and professional community, the author posed the question "Why Marketers Should Study Public Policy" (Stewart 2015) and called for "deeper and richer analyses of public policy issues by marketers" because "marketing disciplines can contribute much to the discussion by addressing the "why" question in depth ... and by identifying the complexity of behaviour in markets, the underlying goals that drive behaviour, the alternatives for achieving these goals, and the likely acceptance or rejection of such alternatives" (id.). Entrepreneurship lends itself well to this type of study because regulating this area would have a significant effect on the behaviour of those involved and this work has identified three possible routes.

In conclusion, then, one additional consideration needs to be made regarding government policy. Mazzucato in 2013 showed that a significant part of certain types of innovation, such as important IPhone components or biomedical products, are no longer the result of private research. At present, though, the State's role in entrepreneurship is confined to overcoming market failures, whereas, perhaps it should also be looking not only at areas where there is no return on investment by private individuals. At the same time, though, the State does play an essential role in sustaining applications which then become profitable for individuals. This situation suggests that the State could be another example of entrepreneurship in the sense that it can help bear the risks involved in making certain choices, and help identify which areas to invest in, just as a private entrepreneur would. Certainly, for any innovative start-up, an Entrepreneurial State, with clear and secure rules, would be a great travelling mate.

\section{Bibliography}

Ács, Z.J., Autio E., and L. Szerb (2014). National systems of entrepreneurship: Measurement issues and policy implications, Research Policy, 43(3) 476-494. http://dx.doi.org/10.2139/ssrn.2008160

Arora A., Gambardella A. and S. Klepper (2005). Organizational capabilities and the rise of the Sofware industry in the Emerging Economies: Lesson from the Histories of Some US Industries in Arora A., Gambardella A. (2005). From underdog to Tigers: The rise and growth of the software industry in Brazil. China, India, Ireland and Israel, Oxford University Press.

Audretsch, D. (2007). The Entrepreneurial Society, Oxford University Press.

Autio, E., Kenney, M., Mustar, P., Siegel, D., and M. Wrigh (2014). Entrepreneurial innovation: The importance of context, Research Policy, 43(7), 1097-1108.

http://dx.doi.org/10.1016/j.respol.2014.01.015

Edited by: ISTEI - University of Milan-Bicocca

ISSN: 1593-0319 
Becattini G. (2004). A new Approach to industrial change, Edward Elgar Publishing.

Brondoni, S. M. (2008). Market-driven management, Competitive Space and Global Networks, Symphonya, Emerging Issues in Management, 1, 14-27.

http://dx.doi.org/10.4468/2008.1.02brondoni

Brondoni, S. M. (2011). Global Networks, Knowledge Management and World Cities, Symphonya. Emerging Issues in Management, 1, 7-18.

http://dx.doi.org/10.4468/2011.1.02brondoni

Brondoni, S.M. (2014). Global Capitalism and Sustainable Growth. From Global Products to Network Globalisation, Symphonya. Emerging Issues in Management, 1, 10-31

http://dx.doi.org/10.4468/2014.1.02brondoni

Brownson C. D. (2013). Fostering Entrepreneurial Culture: A Conceptualization, European Journal of Business and Management, 5.31, 146-154.

Coleman J. (1988). Social capital in the creation of human capital, American Journal of Sociology, 94, 95-120.

Gartner W.B, (1988). Who is the entrepreneur? is the wrong question, Entrepreneurship Theory and Practice, Summer, 47-67.

Granovetter M.S. (1973). The strength of weak ties, American Journal of Sociology, 78, 1368-1380.

Haltiwanger J., Jarmin R.S., and J. Miranda (2013). Who creates jobs? Small versus large versus young, Review of Economics and Statistics 95(2) 347-361.

http://dx.doi.org/10.1162/REST_a_00288

Holly K. (2013). Seven Reasons why Startups Won’t Save the Economy, Forbes September 20.

Jaworski B., Kohli A., and A. Sahay (2000). Market-driven versus driving markets, Journal of the academy of marketing science 28(1), 45-54.

http://dx.doi.org/10.1177/0092070300281005

Kirzner I. (1997). Entrepreneurial discovery and the competitive market process: An Austrian approach, Journal of economic Literature 35(1), 60-85.

Lambin, J.J. (2014). Rethinking the Market Economy, Symphonya. Emerging Issues in Management 2, 4-15.

http://dx.doi.org/10.4468/2014.2.02lambin

Lumpkin, G., Dess G. (1996). Clarifying the entrepreneurial orientation construct and linking it to performance, Academy of management Review 21(1), 135-172.

http://dx.doi.org/10.5465/AMR.1996.9602161568

Mazzucato M. (2013). The Entrepreneurial State: debunking public vs. private sector myths, Anthem Press: London, UK.

McClelland D.C. (1965). N achievement and entrepreneurship: A longitudinal study, Journal of personality and Social Psychology 1(4), 389.

http://dx.doi.org/10.1037/h0021956

Miller D., J.M. (1986). Chief executive personality and corporate strategy and structure in small firms, Management Science, 32(11), 1389-1409.

http://dx.doi.org/10.1287/mnsc.32.11.1389

Ouimet P., Zarutskie R. (2014). Who works for startups? The relation between firm age, employee age, and growth, Journal of financial Economics, 112 (3), 386-407.

http://dx.doi.org/10.1016/j.jfineco.2014.03.003

Presutti, M., Boari, C. (2007). Space-related antecedents of social capital: some empirical inquiries about the creation of new firms, International Entrepreneurship and Management Journal, Special Issue 
(C) SYMPHONYA Emerging Issues in Management, n. 3, 2015

symphonya.unimib.it

http://dx.doi.org/10.1007/s11365-007-0063-y

Rauch A., Frese M. (2007). Let's put the person back into entrepreneurship research: A meta-analysis on the relationship between business owners' personality traits, business creation, and success, European Journal of work and organizational psychology 16(4), 353-385.

http://dx.doi.org/10.1080/13594320701595438

Rosenberg N. (1982). Inside the black box: technology and economics, Cambridge University Press.

Rotter, J. (1966). Generalized expectancies for internal versus external control of reinforcement, Psychological monographs: General and applied 80.1.

http://dx.doi.org/10.1037/h0092976

Shane, Scott, and Sankaran Venkataraman, (2000). The promise of entrepreneurship as a field of research. Academy of management review 25(1) 217-226.

http://dx.doi.org/10.5465/AMR.2000.2791611

Schumpeter J. (1942). Capitalism, Socialism and Democracy, Harper \& Brothers.

Stewart D.W. (2015). Why Marketers Should Study Public Policy, Journal of Public Policy \& Marketing, 34(1), 1-3.

http://dx.doi.org/10.1509/jppm.34.1

Toninelli P., Vasta M. (2010). Boundaries and governance of Italian state-owned enterprise: a quantitative approach. No. 182. University of Milano-Bicocca, Department of Economics.

\section{Notes}

${ }^{1}$ Attributes, mindset, behavior, values (Brownson, 2013).

${ }^{2}$ By favoring a general equilibrium analysis with a static concept and perfect competition, economic theory has completely overlooked the entrepreneur and therefore furnished an extremely simplified, and even reductive view of enterprises. Neoclassical theory claims that technological knowledge is exogenous to the company, and therefore a production factor that requires no specific skills as it is available to everyone. In other words, the company is seen as a technical production center in which optimization decisions are taken, but no one knows how. More accurately, it is seen as a kind of "black box" (Rosemberg, 1982) in which the efficiency of production functions is determined by the technological knowledge available. In this scenario the entrepreneur becomes only a kind of technical controller as there is no uncertainty or risk.

Evidently, this approach has several limitations, starting from the fact that knowledge is treated like information and therefore all aspects of the translation and interpretation of this information and the learning and accumulation processes needed to transform this knowledge into skills are ignored. Since this information is available to all, there are also no incentives for the company to innovate or determine moments of competitive advantage linked to the possession of exclusive skills.

The work "Essay Sur La Nature Du Commerce En Général" written in 1730 reputedly by Cantillon and published in France in $\mathbf{1 7 5 5}$ was the first to use the term "entrepreneur" to identify a person who bears the risk of buying a certain basket of goods for resale, perhaps in another place and at an uncertain price. Many years later, Schumpeter (1942) broke definitively with the tradition of economic theory by introducing the concept of "creative destruction," that explains how innovative companies are always trying to find new market space where a temporary monopoly can generate extra profits.

3 This figure often quoted by the press or in political debate, should be treated with caution and correlated to the age of the enterprise in question (Haltiwanger et al, 2013).

${ }^{4}$ Survey Unioncamere 2014

${ }^{5}$ http://www.bancaditalia.it/pubblicazioni/altri-atti-convegni/2014-innovazione-italia/Aimone-GigioMancini.pdf 